International Indian Ocean Expedition, in which the United States has 14 ships and 5 aircraft participating; 1.5 million dollars towards some 20 projects for the modification of the weather; 448,000 dollars for 5 projects in a co-operative scionco programme with Japan; and 3.7 million dollars for 48 projects in the International Year of the Quiet Sun.

Contributions to specialized research facilities included $5 \cdot 3$ million dollars for oceanographic vessels and facilities, 3.5 million dollars on 19 grants for biological research facilities, 4.5 million dollars on 18 grants for university computer installations, 5 million dollars for nuclear research facilities at universities, 700,000 dollars on 14 grants for university research facilities in atmospheric sciences, and 1 million dollars on 6 grants for research facilities in social science.

Under its scionce education programme, the Foundation awarded 3,226 graduate fellowships, 96 senior postdoctoral fellowships, 240 postdoctoral fellowships, 908 summer fellowships for graduate teachers, 325 scicnee faculty fellowships and 292 summer fellowships for secondary school teachers, as well as 43 senior foreign science fellowships to scientists invited from other countries by universitios in the United States. Nuch assistance was directed towards improving undergraduate courses, and nearly 9 million dollars went for equipment for this purpose and 688 institutions were assisted. The
Foundation contributed 39 million dollars towards institute training for secondary school teachers, 35,000 of whom attended such courses. Much progress is also reportod on improving secondary school courses, and the Foundation also made grants totalling 2.4 million dollars for 185 special projects which provided training opportunities for 7,600 specially talented secondary school students. Attention was also given to the needs of olemontary school teachers, about 3,350 of whom will receive training in teaching in science or mathematics as a result of Foundation grants, and the improvement of elernentary school courses in science is also boing assisted.

During the year the Foundation made six grants totalling 180,000 dollars in support of new periodicals, for the elimination of arrears and for experiments in more efficient production of periodicals; 17 grants totalling 140,000 dollars were awarded for the publication of scientific monographs; 390,000 dollars was awarded for the development by the Chemical Abstracts Service of a system of mechanical control of more than 2 million chemical structures with related technical information as a basis for a nation:al computer-basod chemical information service. Sevonteen grants amounting to 859,000 dollars were made for research into the organization and searching of information, and during the year the Founda. tion supported 54 periodicals of translations, of which 10 became self-supporting during the year.

\title{
WILDLIFE RESEARCH IN THE UNITED STATES
}

$\mathrm{T}$ HE activities of the Division of Wildlife Research in the Bureau of Sport, Fisheries and Wildlife of the U.S. Department of the Interior are described in the recently published report for $1963 *$. The Division serves as the fact-finding part of the Bureau, responsible for research on all wildlife-game and non-game, resident and migratory, harmful and beneficial. The results of the Division's investigations are used by the Burean, and by co-operating Federal and State agencies in wildlife management, not only for the production of more and better public recreational facilities, but also for more effective control of wildlife injurious to agricultural, industrial and urban interests.

The research of the Division at present involves waterfowl and other migratory birds, upland wildlife with particular emphasis on problems occurring on public lands, pesticide-wildlife relations, diseases and parasites, control mothods, and classification, distribution and life studies of wild birds and animals. Marine mammal research is at present being concentrated on the sea otter.

The expansion of the research programmes that began in 1958 continued, and programmes in animal-control methods and pesticide-wildlife relations were introduced. Disease and parasite research in the field of resident wildlife was expanded during tho year through a contract with the University of Georgia. Smaller but significant growth characterized research on water-fowl and other migratory birds.

In meeting its wildlife research responsibilities, the Division co-operates with other agencies of the Department of the Interior, the Department of Agriculture, the Department of Health, Education and Welfare, and the Department of Defence. In its game-bird introduction programme, it is co-operating with the Wildlife Management Institute, the International Association of Game, Fish and Conservation Commissioners, more than forty State conservation departments, and various foreign

* United States Department of the Interior: Fish and Wildilfe Service. Bureall of Sport, Fisheries and Wildlife. Circular 188: W ildife ResearchProblems, Programs, Progress, countries. Much of this research is in the native ranges of game birds considered potentially adaptable for release in selected game-deficient areas in the United States.

One of the oldest and best known of the Division's co-operative programmes is that of the Co-operative Wildlife Research Units. These are supported and administered under the terms of a memorandum of understanding signed by officials of the Bureau, the Wildlife Management Institute, and the land grant colleges and game and fish departments of the oighteen participating States. In addition to research, the Units facilitate training of qualified graduate students in wildlife studies and promote education in conservation through publication, demonstration, lecture and consultation.

The Division is concerned with numerous other instances of co-operative research, made possible by the interest of various conservation agencies, scientific institutions, and individuals. These programmes include the birdbanding record centre at the Migratory Bird Populations Station at Laurel, Maryland, where banding data on nearly 12 million birds of all kinds and recovory records on more than 1 million migratory birds are filed, and where more than 3 million cards on the migration and distribution of North American birds are housed. In another co-operative programme, bats have been banded, and the records are filed and kept up to date in the Bird and Mammal Laboratories housed in the U.S. National Museum.

The world's largest collections of North American birds and mammals are maintained at the U.S. National Museum, in co-operation with the Smithsonian Institution. These records, together with the professional taxonomic services provided by Division employees, are available to investigators whether they are members of the Bureau or not. The assistance of thousands of banders, observers and collectors, who have co-operated in obtaining these specimens or in providing data on them, makos this comprehensive service possible.

Within the Division the directors of the five research centres, the leaders of the eighteen Co-operative Wildlife Research Units, the leader of the foreign game introduction 
project, and the editor all report directly to the central office in Washington. Programme planning, co-ordination, and the administration for all Division research are functions of the Washington office. Routine fiscal, personnel, and property management of field research stations are handled through the five regional offices of the Bureau.

In the fiscal year 1964 the Division had 190 professional and 160 clerical or other employees, and a budget of about 4.5 million dollars.

\section{BREATHLESSNESS}

$\mathrm{D}$ URING April 7-8, a symposium on "Breathlessness" was held at the University of Manchester, sponsored by the pharmaceutical company Boehringer Ingelheim, Ltd., which brought together neurophysiologists, respiratory physiologists and clinicians of several specialties.

After the meeting was opened by Prof. D. A. K. Black (Manchester), Dr. J. H. Comroe (San Francisco) in an introductory talk commented that he would have preforred the meeting to be restricted to dyspnoea and to have excluded other disturbances such as hyperpnoea and tachypnoea which, although called 'breathlessness', should be distinguished from difficulty in breathing. $\mathrm{He}_{\Theta}$ reviewed the methods by which dyspnoea has been studied and the theories which have been propounded.

Dr. A. J. Buller (London), who described present-day views on the organization and function of the muscle spindles, emphasized the different properties of the nuclear bag and nuclear chain systems and indicated how these may function in control of movement. Dr. C. von Euler (Stockholm) showed how the $\alpha$ - and $\gamma$ - motor systoms operated in the respiratory muscles of cats, emphasizing the difference botwoen the intercostals and the diaphragm. Dr. T. A. Sears (London) deseribed. investigations of single anterior horn cells of cat intercostals, which showed how much integration of excitatory and inhibitory drives may occur at this level.

In the second session, under the chairmanship of Dr. J. H. Comroo, Dr. E. J. M. Campbell (London) reviowed the ways in which information about ventilation and the act of breathing may reach consciousness, and discussed the theory of length : tension appropriateness and the distinction between awareness and distress. In discussion, Dr. A. Guz (London) described investigations of the effect of vagal interruption in anaesthetized and conscious man. These indicated that the vagus plays only a small part in normal breathing, but may provide a potent drive to respiration and subserve the unpleasant sensation associated with low lung volumes. Dr. J. Nowsom Davis (London) described investigations of patients with neurological disorders which he interpreted as indicating that roceptors in rib joints subserve the awareness of increased resistance to breathing.

Dr. J. Severinghaus (San Francisco) reviewed the evidence that ventilation is normally regulated to maintain constant $p \mathrm{H}$ of cerebrospinal fluid on the surface of the medulla and described how other chemical stimuli interact. Dr. J. E. Cotes (Pneumoconiosis Research Unit, Penarth) discussed the relative importance of central and peripheral neurogenic and chemical drives to ventilation during exercise. In diseussion, Dr. D. J. C. Cunningham (Oxford), Dr. P. Dejours (Paris) and Dr. S. J. G. Sample (London) analysed further the interaction of central and peripheral chemical drives at rest and exercise.

In the third session, under the chairmanship of Sir Robert Platt, Dr. J. Mead (Harvard) described methods of recording respiratory movement which overcame the disadvantages of mouth-pieces and spirometers. $\mathrm{H}_{\theta}$ described (supplemented in discussion by Dr. E. Agostini of Milan) recent work on the interaction of volume and shape in the respiratory act and indicated that forces due to distortion must be added to the conventional elastic and non-elastic forces in the analysis of the mech- anics of breathing. Phase shifts between different parts of the chest and abdomen were discussed by several speakers.

In introducing a session devoted to breathlessness in disease, Prof. C. H. Stuart-Harris (Sheffield) once more urged that a distinction be observed between undue hyperventilation and difficulty in breathing, and asked the following speakers if the sensation of difficulty varied in different conditions, if there may be multiple mechanisms and what are these mechanisms.

Dr. J. B. L. Howell (Manchester) examined breathlessness in respiratory disease, concentrating particularly on the problem of patients with chronic obstruction of air-passages. He marshalled evidence that the obstruction of air-passages itself is insufficient to account for underventilation in all patients and discussed the control of ventilation at rest and exercise. He also discussed the respiratory mechanics and indicated how length : tension inappropriatenoss might occur although the work of breathing is not excessive. Dr. M. B. McIlroy (San Francisco) briefly reviewed possible mechanisms of dyspnoea in hoart disease, but concentrated on studies of patients with metabolic disorders of muscle which indicated how muscular dysfunction could cause, or aggravate, the sensation of dyspnoea. Dr. F. Plum (New York) described the disturbance of breathing in patients with lesions at various levels of the central nervous system. He suggested that there is a hierarchical representation of (in ascending order) diaphragm, intercostals and accessory muscles and that the excessive use of the more highly represented ones may cause dyspnoea.

In discussion Dr. J. M. Petit (Liège) suggested that stresses in the lung generated by unequal time-constants in parallel respiratory pathways might cause discomfort or pain. Dr. R. Marshall (Oxford) described the effects of pulmonary embolism; the hyperpnoea commonly seen remains difficult to explain. Dr. E. R. Hitchcock (Manchester) described the effects of cordotomy at varying sites on the breathing.

In the final general discussion, under the chairmanship of Prof. R. V. Christie (Montreal), Dr. I. Priban of London described a model of respiration as a self-optimizing system. Dr. J. Widdicombe (Oxford) and Dr. M. Noble (London) described their sensations during bilateral vagal block. Dr. B. H. Burns (Manchester) described the psychological features of patients with chronic respiratory disease where reaction to their disability aggravated the complaint of dyspnoea. Dr. C. von Euler suggested that it might be profitable to investigate breathlessness in the same way as thirst and hunger have been investigated experimentally. Dr. C. M. Fletcher (London) gave a classification of breathlessness under the headings of awareness of increased ventilation, difficult ventilation and need for ventilation.

When the opening speakers were invited to make final comments Dr. A. Buller briefly summarized present views on the anatomical basis of sensation indicating the different roles attributed to the sensory cortex and the subcortical centrencephalic region. Dr. F. Plum emphasized that in view of the speed of neuronal and synaptic processes there is little prospect in experiments in man of distinguishing sensation generated by afferents, from sensation 